\title{
PENGARUH KETERAMPILAN MEMBACA PEMAHAMAN TERHADAP KEMAMPUAN PEMECAHAN SOAL CERITA MATEMATIKA PESERTA DIDIK KELAS V SEKOLAH DASAR
}

\author{
Rosselina Tria Andanik, Meita Fitrianawati \\ Universitas Ahmad Dahlan \\ deya.tria15@gmail.com
}

\begin{abstract}
This study aims to determine the effect of reading comprehension skills on the mathematical problem-solving ability of fifth-grade students of Muhammadiyah Elementary School Ambarbinangun. This study uses a quantitative research approach with an ex-post facto type of research. The research subjects in this study were the fifth-grade students of Muhammadiyah Ambarbinangun Elementary School, amounting to 66 students. The variables studied were reading comprehension skills (Variable X) and the ability to solve mathematical story problems (Variable Y). Data collection techniques in this study used test that had been tested for validity and reliability and also used interview. Hypothesis testing uses simple linear regression analysis and Pearson correlation with the help of SPSS version 20. The results of the research that were processed using a simple linear regression test and Pearson correlation test showed that reading comprehension skills had a significant effect on the ability to solve mathematical story problems. less than 0.05 which is equal to 0,000 with a simple linear regression equation $Y=1,500+0,612 X$. For Pearson Correlation obtained at 0.746 so that when viewed from the guidelines the degree of relationship that has been listed, the Pearson correlation is strongly correlated. So it can be concluded that reading comprehension skills have a positive effect on the ability to solve mathematical story problems with a strong degree of correlation.
\end{abstract}

Keywords : reading comprehension, mathematical story questions, grade $v$ elementary school

\section{ABSTRAK}

Penelitian ini bertujuan untuk mengetahui pengaruh keterampilan membaca pemahaman terhadap kemampuan pemecahan soal cerita Matematika peserta didik kelas V SD Muhammadiyah Ambarbinangun. Penelitian ini menggunakan pendekatan penelitian kuantitatif dengan jenis penelitian ex-post facto. Subjek penelitian dalam penelitian ini adalah peserta didik kelas V SD Muhammadiyah Ambarbinangun yang berjumlah 66 peserta didik. Variabel yang diteliti yaitu keterampilan membaca pemahaman (Variabel X) dan kemampuan pemecahan soal cerita Matematika (Variabel Y). Teknik pengumpulan data dalam penelitian ini menggunakan tes yang telah diuji validitas dan reliabilitasnya, dan juga menggunakan wawancara. Pengujian hipotesis menggunakan analisis regresi linier sederhana dan korelasi pearson dengan bantuan program SPSS versi 20. Hasil penelitian yang diolah menggunakan uji regresi linier sederhana dan uji korelasi pearson menunjukkan bahwa keterampilan membaca pemahaman berpengaruh signifikan terhadap kemampuan pemecahan soal cerita Matematika, hal ini ditunjukkan dengan nilai sig kurang dari 0,05 yaitu sebesar 0,000 dengan persamaan regresi linier sederhana $\mathrm{Y}=1,500$ $+0,612$ X. Untuk Pearson Correlation diperoleh sebesar 0,746 sehingga jika dilihat dari 
pedoman derajat hubungan yang sudah tertera, pearson correlationnya adalah berkorelasi kuat. Sehingga dapat disimpulkan bahwa keterampilan membaca pemahaman berpengaruh positif terhadap kemampuan pemecahan soal cerita Matematika dengan derajat hubungan korelasi kuat.

Kata kunci: membaca pemahaman, soal cerita matematika, sd kelas v

\section{PENDAHULUAN}

Proses pengembangan dan pembentukan watak yang paling mendasar pada peserta didik di Sekolah Dasar adalah keterampilan berbahasa, keterampilan berbahasa dikembangkan dalam pembelajaran Bahasa Indonesia. Tujuan adanya pembelajaran tersebut agar peserta didik memiliki kemampuan berbahasa indonesia yang baik dan benar, secara lisan maupun tertulis. Seperti halnya yang dikemukakan oleh Saddhono \& Slamet (2014 : 5) ada empat aspek keterampilan berbahasa yaitu menyimak, membaca, berbicara, dan menulis. Keempat keterampilan inilah sebagai modal peserta didik dalam berkomunikasi sehari-hari. Dalam keterampilan membaca terdapat keterampilan membaca pemahaman. Somadayo (2011 : 10) menjelaskan bahwa kemampuan membaca pemahaman merupakan suatu proses pemerolehan makna yang secara aktif melibatkan pengetahuan dan pengalaman yang telah dimiliki oleh pembaca serta dihubungkan dengan isi bacaan. Membaca pemahaman tidak hanya diperlukan peserta didik dalam mengikuti mata pelajaran Bahasa Indonesia saja, namun hampir semua mata pelajaran membutuhkan kemampuan membaca pemahaman yang memadai. Keterampilan membaca pemahaman yang seharusnya sudah dikuasi peserta didik ini dianggap masih rendah di Indonesia seperti yang dijelaskan Krismanto (2015 : 235) didukung oleh data yang diperoleh dari Studi Internasional yakni Program Student International Assesment (PISA) tahun 2006 menunjukkan bahwa kemampuan literasi membaca peserta didik di Indonesia berada pada peringkat ke-48 dari 56 negara. Skor rata-rata membaca yang diperoleh peserta didik Indonesia adalah 393. Kemampuan membaca tersebut dipengaruhi oleh kemampuan yang masih rendah, diantaranya dalam hal: memahami ide paragraf, membaca grafik, memahami hubungan antar fakta, hubungan logika linguistik, dan menemukan ide bacaan. Studi lain tentang kemampuan membaca yakni Progress in International Reading Literacy Study (PIRLS) tahun 2006, menyatakan bahwa kemampuan peserta didik SD di Indonesia tergolong rendah. Rata-rata kemampuan membaca pemahaman hanya sekitar $30 \%$.

Nurgiyantoro (2011: 370) mengemukakan kompetensi membaca yang baik diperlukan dan menjadi prasyarat untuk dapat membaca dan memahami berbagai literatur mata pelajaran yang lain, contohnya mata pelajaran IPS, IPA, PKn, dan Matematika. Membaca pemahaman pada mata pelajaran Matematika khususnya terdapat di dalam soal cerita. Matematika terdapat hal utama dalam menyelesaikan masalah Matematika adalah pemahaman terhadap masalah yang terdapat di dalam soal. Raharjo, dkk (2011:8) mengatakan bahwa soal cerita yang terdapat dalam Matematika merupakan persoalanpersoalan yang terkait dengan permasalahan-permasalahan dalam kehidupan sehari-hari yang dapat dicari penyelesaiannya dengan menggunakan kalimat Matematika. Kalimat Matematika yang dimaksud dalam penyataan tersebut adalah kalimat Matematika yang memuat operasi hitung bilangan. Menurut Winarni dan Harmini (2011:124) menjelaskan bahwa dalam memecahkan masalah dibutuhkan pemikiran dan kerja keras untuk menerima tantangan agar mampu memecahkan masalah yang dihadapi. Sedangkan menurut Siswono (2008:36) Seseorang yang dihadapkan pada suatu permasalahan tidak serta merta dapat menyelesaikan permasalahan tersebut dengan mudah. Perlu adanya ketrampilan empiris yang berhubungan dengan perhitungan, pengukuran), ketrampilan aplikatif untuk 
menghadapi situasi yang umum atau sering terjadi, dan ketrampilan berpikir untuk bekerja pada suatu situasi yang tidak biasa. Kemampuan menyelesaikan masalah Matematika ini dianggap masih rendah didukung dari jurnal Rahmawati tahun 2016 dalam seminar hasil TIMSS (Trends International Mathematics and Science Study) pada tahun 2015 menyebutkan bahwa peserta didik masih lemah di semua domain konten maupun kognitif, baik untuk Matematika maupun sains. Terutama di dalam Matematika, kemampuan peserta didik masih minim pada soal-soal dalam domain bernalar yang membuktikan bahwa penguasaan pemecahan masalah Matematika masih rendah.

Secara umum pada soal cerita Matematika terkandung konsep Matematika, seperti pengalian, penambahan, pengurangan, dan pembagian. Permasalahan dalam soal cerita Matematika dapat diselesaikan dengan perencanaan yang matang dan langkah-langkah yang runtut seperti yang dijelaskan oleh George Polya (Setiyoko, $2016: 25-27$ ) meliputi : (1) memahami masalah; (2) membuat rencana untuk menyelesaikan masalah; (3) melaksanakan rencana yang telah dibuat; (4) memeriksa ulang jawaban yang diperoleh. Oleh karena itu, untuk menyelesaikan soal cerita, peserta didik harus mengonversikan dalam bentuk angka. Dengan demikian, terjadi dua proses yang dilakukan peserta didik, yaitu proses pemahaman rangkaian kalimat cerita dan proses pengonversian rangkaian kalimat cerita menjadi angka. Pengonversian rangkaian kalimat cerita menjadi angka memerlukan keterampilan pemahaman teks bacaan atau dikenal dengan nama membaca pemahaman. Pengkonversian akan berjalan dengan lancar jika peserta didik memahami teks bacaan dengan baik dan memahami konsep hitungan Matematika, seperti pengalian, penambahan, pengurangan, dan pembagian. Kedua hal ini saling berhubungan dan sangat diperlukan untuk memahami dan menyelesaikan soal hitungan cerita (Auzar, 2013 : 34). Kemampuan memahami bahasa Matematika hitungan cerita memiliki hubungan dengan kemampuan membaca pemahaman karena kedua-dua kemampuan ini sama-sama menangkap makna yang terkandung di dalam teks. Hal ini juga didukung dengan penelitian sebelumnya yang menyebutkan bahwa keterampilan membaca pemahaman berpengaruh terhadap kemampuan pemecahan soal cerita Matematika.

\section{METODE PENELITIAN}

Jenis penelitian yang digunakan yaitu penelitian kuantitatif. Penelitian ini akan dilaksanakan di SD Muhammadiyah Ambarbinangun, Tirtonimolo, Kasihan, Bantul. Waktu penelitian akan dilaksanakan pada semester II tahun ajaran 2018/2019 pada tanggal 26-30 April 2019. Subjek dari penelitian ini adalah semua peserta didik kelas V SD Muhammadiyah Ambarbinangun yang terdiri dari dua kelas yang masing-masing terdiri dari 33 peserta didik, kemudian diambil 46 peserta didik sebagai sampel. Teknik pengumpulan data menggunakan tes dan wawancara. Tes adalah sekumpulan pertanyaan atau soal yang digunakan untuk mengukur keterampilan, kemampuan, pengetahuan atau bakat yang dimiliki oleh seseorang. Teknik ini dilakukan untuk melengkapi data yang dibutuhkan yaitu untuk mengetahui sejauh mana keterampilan membaca pemahaman dan kemampuan pemecahan soal cerita Matematika peserta didik. Tes yang diberikan berkaitan dengan keterampilan membaca pemahaman peserta didik dan kemampuan peserta didik dalam pemecahan soal cerita Matematika. Teknik tes yang digunakan menggunakan bentuk tes objektif atau pilihan ganda dan tes uraian. Tes objektif digunakan untuk mengukur keterampilan membaca pemahaman. Hal ini disebabkan antara lain luasnya bahan pelajaran yang harus di uji dalam tes dan untuk mempermudah proses penilaian yang akan dilakukan peneliti. Sedangkan tes uraian digunakan untuk mengukur 
kemampuan pemecahan soal cerita Matematika. Teknik analisis data menggunakan teknik regresi linier sederhana dan korelasi pearson.

\section{HASIL DAN PEMBAHASAN}

a. Hasil Validasi dan Reliabilitas Instrumen

1. Hasil Uji Validitas Variabel X

Diperoleh nilai $\mathrm{r}$ tabel sebesar 0,404, jika $\mathrm{r}$ hitung $>\mathrm{r}$ tabel maka soal valid. Dengan bantuan SPSS terdapat 9 soal yang $\mathrm{r}$ hitungnya lebih besar dari $\mathrm{r}$ tabel sebesar 0,404.

2. Hasil Uji Reliabilitas Variabel X

Instrumen dikatakan reliabel apabila nilai Cronbach's Alpha lebih dari 0,6. Nilai Cronbach's Alpha diperoleh nilai 0,770 maka dapat disimpulkan alat ukur yang digunakan dalam penelitian reliabel.

3. Hasil Uji Validitas Variabel Y

Diperoleh nilai $r$ tabel sebesar 0,455, jika $r$ hitung $>r$ tabel maka soal valid. Dengan bantuan SPSS terdapat 4 soal yang $r$ hitungnya lebih besar dari $r$ tabel sebesar 0,455 .

4. Hasil Uji Reliabilitas Variabel Y

Instrumen dikatakan reliabel apabila nilai Cronbach's Alpha lebih dari 0,6. Nilai Cronbach's Alpha diperoleh nilai 0,702 maka dapat disimpulkan alat ukur yang digunakan dalam penelitian reliabel.

b. Hasil Analisis Deskriptif

Keterampilan membaca pemahaman merupakan suatu kegiatan serta kesanggupan peserta didik dalam memahami isi teks bacaan, yang dalam penelitian ini teks bacaan berupa cerita pendek. Keterampilan membaca pemahaman ini diukur dengan menggunakan tes berjumlah 10 butir soal yang sudah diuji validitas dan reliabilitasnya. Tes dikerjakan oleh 60 peserta didik dan selanjutnya diambil 46 peserta didik sebagai sampel. Data yang telah diperoleh diberi skor, jawaban benar diberi skor 2, jawaban salah diberi skor 1 dan jika tidak menjawab diberi skor 0 . Hasil penelitian menunjukkan bahwa data sebagai berikut.

Tabel 1. Deskripsi Data Keterampilan Membaca Pemahaman

\begin{tabular}{|l|l|l|l|l|l|l|}
\hline $\mathbf{N}$ & Mean & Median & Mode & Std. Deviation & Minimum & Maximum \\
\hline 46 & 6,9130 & 6,5000 & 6,50 & 1,07525 & 4,50 & 8,50 \\
\hline
\end{tabular}

Kemampuan pemecahan soal cerita Matematika diukur dengan menggunakan tes berjumlah 4 butir soal yang sudah diuji validitas dan reliabilitasnya. Tes dikerjakan oleh 60 peserta didik dan selanjutnya diambil 46 peserta didik sebagai sampel. Data yang telah diperoleh diberi skor sesuai dengan rubrik penskoran kemampuan menyelesaikan soal cerita Matematika. Berdasarkan data kemampuan pemecahan soal cerita Matematika yang diolah menggunakan program SPSS 20 diketahui hasil statistik deskriptifnya. Hasil statistik deskriptif kemampuan pemecahan soal cerita menunjukkan data sebagai berikut:

Tabel 2. Deskripsi Data Kemampuan Pemecahan Soal Cerita Matematika

\begin{tabular}{|l|l|l|l|l|l|l|}
\hline N & Mean & Median & Mode & Std. Deviation & Minimum & Maximum \\
\hline
\end{tabular}




\begin{tabular}{|l|l|l|l|l|l|l|}
\hline 46 & 5,7326 & 5,7000 & 6,70 & 0,88294 & 3,70 & 6,80 \\
\hline
\end{tabular}

\section{c. Hasil Analisis Korelasi}

Hasil perhitungan regresi linier sederhana dan korelasi pearson sama-sama menunjukkan nilai signifikansi 0,000 yang berarti $0,000<0,05$, berarti dapat disimpulkan bahwa variabel Keterampilan Membaca Pemahaman (X) berpengaruh terhadap variabel Kemampuan Penyelesaian Soal Cerita Matematika (Y). Diperoleh juga t hitung sebesar 7,423 dan t tabel sebesar 2,015, sehingga dapat disimpulkan bahwa variabel Keterampilan Membaca Pemahaman (X) berpengaruh terhadap variabel Kemampuan Penyelesaian Soal Cerita Matematika $(\mathrm{Y})$ karena $t$ hitung $>\mathrm{t}$ tabel $(7,423>2,015)$. persamaan regresi linier sederhana $(\mathrm{Y}=\mathrm{a}+\mathrm{bX}$ ) diperoleh persamaannya yaitu $\mathrm{Y}=1,500+0,612 \mathrm{X}$, Persamaan tersebut menjelaskan, jika peserta didik tidak memiliki nilai keterampilan membaca pemahaman $(\mathrm{X}=0)$ maka peserta didik memiliki nilai kemampuan penyelesaian soal cerita Matematika sebesar 1,500 dan apabila peserta didik memiliki nilai keterampilan membaca pemahaman $1(X=1)$ maka nilai kemampuan penyelesaian soal cerita Matematika akan bertambah sebesar 0,612. Koefisien regresi tersebut bernilai positif, sehingga dapat dikatakan bahwa arah pengaruh variabel $\mathrm{X}$ terhadap variabel $\mathrm{Y}$ adalah positif. Hasil tersebut juga menjelaskan bahwa keterampilan membaca pemahaman berpengaruh signifikan terhadap kemampuan penyelesaian soa cerita Matematika. Artinya semakin baik keterampilan membaca pemahaman peserta didik kelas V SD Muhammadiyah Ambarbinangun maka semakin baik pula kemampuan penyelesaian soal cerita Matematika. Untuk Pearson Correlation diperoleh sebesar 0,746 sehingga jika dilihat dari pedoman derajat hubungan yang sudah tertera, pearson correlationnya adalah berkorelasi kuat. Sehingga dapat disimpulkan bahwa Keterampilan Membaca Pemahaman berpengaruh positif terhadap Kemampuan Pemecahan Soal Cerita Matematika dengan derajat hubungan korelasi kuat.

\section{d. Pembahasan}

Hasil penelitian dari kemampuan membaca pemahaman menunjukkan adanya pengaruh positif dan signifikan terhadap kemampuan pemecahan soal cerita Matematika peserta didik kelas V SD Muhammadiyah Ambarbinangun. Bernilai positif berarti semakin tinggi tingkat keterampilan membaca pemahaman peserta didik maka semakin tinggi pula kemampuan peserta didik dalam pemecahan soal cerita Matematika dan sebaliknya. Hasil penelitian menunjukkan perolehan nilai signifikansi sebesar 0,000 yang berarti $0,000<0,05$ dengan pearson correlation sebesar 0,746, maka dapat disimpulkan bahwa keterampilan membaca pemahaman berpengaruh positif terhadap kemampuan pemecahan soal cerita Matematika dengan derajat hubungan korelasi kuat.

Hasil penelitian ini sejalan dengan hasil penelitian sebelumnya yaitu penelitian Calista dimana diperoleh nilai perhitungan korelasi Product Moment sebesar 0,72 yang membuktikkan adanya hubungan yang signifikan dari kemampuan membaca pemahaman dengan penyelesaian masalah Matematika peserta didik kelas IV SDN se-Kabupaten Malang, dimana hasilnya bernilai positif, artinya semakin tinggi kemampuan membaca pemahaman peserta didik maka semakin tinggi pula tingkat kemampuan peserta didik dalam menyelesaikan masalah berupa soal cerita Matematika. Hasil penelitian yang lain yaitu penelitian Setiyoko diperoleh nilai signifikansi hasil uji regresi sederhana lebih kecil dari 0,05 yaitu sebesar 0,000 yang membuktikkan bahwa keterampilan membaca pemahaman berpengaruh signifikan terhadap kemampuan menyelesaikan soal cerita Matematika pada peserta didik kelas IV SD segugus IV Kecamatan Pengasih Kabupaten 
Kulon Progo tahun ajaran 2015/2016, dan perolehan persamaan regresi $\mathrm{Y}=0,773+$ $0,904 \mathrm{X}$ yang artinya semakin tinggi keterampilan membaca pemahaman peserta didik maka semakin tinggi pula kemampuan menyelesaikan soal cerita Matematika peserta didik.

Berdasarkan hasil wawancara yang dilakukan peneliti kepada guru tentang keterampilan membaca pemahaman diperoleh informasi bahwa sebagian peserta didik sudah menguasai keterampilan membaca pemahaman, untuk hasil belajar peserta didik secara keseluruhan sudah bagus namun memang ada sedikit kendala dalam proses belajar mengajar yaitu peserta didik yang tidak mau memperhatikan guru yang sedang mengajar. Untuk kemampuan pemecahan soal cerita peserta didik kelas V di SD Muhammadiyah Ambarbinangun tergolong rendah. Masih banyak peserta didik yang susah untuk memahami pelajaran Matematika sehingga peserta didik malas dalam mengerjakan soal Matematika. Peneliti juga melakukan wawancara kepada peserta didik tentang keterampilan membaca pemahaman, diperoleh informasi bahwa ada beberapa peserta didik yang tidak menyukai soal dalam bentuk isian singkat karena dianggap menyulitkan, "sudah membaca panjang-panjang juga harus menjawab soal dengan menuliskan jawaban yang panjang-panjang, capek bu" begitu kata salah satu peserta didik. Banyak juga peserta didik yang mengatakan lebih menyukai soal dalam bentuk pilihan ganda. Namun, dari hasil jawaban yang sudah dikoreksi oleh peneliti banyak peserta didik yang mendapatkan nilai yang baik. Untuk kemampuan pemecahan soal cerita Matematika peneliti juga mendapatkan informasi bahwa sekiranya dalam satu kelas seluruh peserta didik sepakat bahwa soal Matematika yang diberikan oleh peneliti adalah soal yang sulit walaupun materi soal yang diberikan sudah diajarkan oleh guru kelas masing-masing. Masih banyak juga peserta didik yang belum paham apa yang harus diisikan di bagian diketahui, ditanyakan, dijawab dan kesimpulan. Walaupun saat ditanya sudahkah diajarkan cara mengerjakan Matematika dengan metode seperti itu mereka menjawab sudah tetapi dengan embel-embel bahwa mereka lupa cara mengerjakannya.

\section{SIMPULAN}

Berdasarkan hasil penelitian tentang keterampilan membaca pemahaman dengan kemampuan penyelesaian soal cerita Matematika peserta didik kelas V SD Muhammadiyah Ambarbinangun, peneliti dapat menyimpulkan antara lain sebagai berikut. Keterampilan membaca pemahaman peserta didik kelas V SD Muhammadiyah Ambarbinangun tergolong kategori baik. Hal ini dibuktikkan dengan nilai rata-rata peserta didik sebesar 6,91. Nilai minimum keterampilan membaca pemahaman peserta didik sebesar 4,5 dan nilai maksimum sebesar 8,5, (2) Kemampuan pemecahan soal cerita Matematika peserta didik kelas V SD Muhammadiyah Ambarbinangun tergolong kategori baik. Hal ini dibuktikkan dengan nilai rata-rata peserta didik sebesar 5,73. Nilai minimum kemampuan pemecahan soal cerita Matematika sebesar 3,7 dan nilai maksimum sebesar 6,8 , (3) Ada pengaruh yang signifikan antara keterampilan membaca pemahaman terhadap kemampuan pemecahan soal cerita Matematika peserta didik kelas V SD Muhammadiyah Ambarbinangun dengan hasil nilai perhitungan signifikansi regresi linier sederhana sebesar 0,000. Nilai signifikansi $<0,05$ yaitu $0,000<0,05$, jika dilihat dari t hitung diperoleh bahwa nilai t hitung sebesar 7,423. Nilai t hitung $>\mathrm{t}$ tabel yaitu 7,423>2,015 dengan perolehan persamaan regresi $\mathrm{Y}=1,500+0,612 \mathrm{X}$ yang artinya semakin tinggi keterampilan membaca pemahaman peserta didik maka semakin tinggi pula kemampuan pemecahan soal cerita Matematika peserta didik. Dalam uji korelasi pearson juga diperoleh nilai signifikansi yang sama yaitu 0,000 . Nilai signifikansi $<0,05$ yaitu $0,000<0,05$ dengan perolehan pearson correlationnya sebesar 0,746 sehingga jika dilihat dari pedoman 
derajat hubungan yang sudah tertera, pearson correlationnya adalah berkorelasi kuat. Sehingga dapat disimpulkan bahwa Keterampilan Membaca Pemahaman berpengaruh positif terhadap Kemampuan Pemecahan Soal Cerita Matematika dengan derajat hubungan korelasi kuat.

\section{DAFTAR PUSTAKA}

Auzar. 2013. Hubungan Kemampuan Membaca Pemahaman dengan Kemampuan Memahami Bahasa Soal Hitungan Cerita Matematika Peserta didik-Peserta didik Kelas 5 SD 006 Pekanbaru. Jurnal Bahas. Vol 8. Nomor 1. Hal 34.

Calista, K, dkk. Hubungan Antara Kemampuan Membaca Pemahaman dengan Penyelesaian Masalah Matematika Peserta didik Kelas IV di SDN Se-Kabupaten Malang. Hal 283. Skripsi

Krismanto, Wawan, dkk. 2015. Meningkatkan Kemampuan Membaca Pemahaman Melalui Metode Survey, Question, Read, Recite, Review (SQ3R) Pada Peserta didik Kelas IV SD Negeri 46 Parepare. Jurnal Publikasi Pendidikan. Vol. 5. Hal 235.

Nurgiyantoro, Burhan. 2011. Penilaian Pembelajaran Bahasa. Yogyakarta : BPFE

Raharjo, Marsudi., Astuti Waluyati. 2011. Pembelajaran Soal Cerita Operasi Hitung Campuran di Sekolah Dasar. Yogyakarta : PPPPTK Matematika.

Saddhono, K dan Slamet. 2014. Pembelajaran Keterampilan Berbahasa Indonesia. Yogyakarta : Graha Ilmu.

Setiyoko. 2016. Pengaruh Keterampilan Membaca Pemahaman Terhadap Kemampuan Menyelesaikan Soal Cerita Matematika Peserta didik Kelas IV Sekolah Dasar Gugus IV Kecamatan Pengasih. Hal 8.

Siswono, T.Y.E. 2008. Model Pembelajaran Matematika Berbasis Pengajuan dan Pemecahan Masalah untuk Meningkatkan Kemampuan Berpikir Kreatif. Surabaya : Unesa University Press.

Somadyo, Samsu. 2011. Strategi dan Teknik Pembelajaran Membaca. Yogyakarta : Graha Ilmu.

Winarni dan Harmini. 2011. Matematika untuk PGSD. Bandung : Remaja Rosdakarya. 